\title{
Detecting and mapping annual newly-burned plots (NBP) of swiddening using historical Landsat data in Montane Mainland Southeast Asia (MMSEA) during 1988-2016
}

\author{
LI Peng ${ }^{1,2}$, FENG Zhiming ${ }^{1,2}$, XIAO Chiwei ${ }^{1,2}$, BOUDMYXAY Khampheng ${ }^{1,2}$, \\ LIU $\mathrm{Yu}^{1}$ \\ 1. Institute of Geographic Sciences and Natural Resources Research, CAS, Beijing 100101, China; \\ 2. College of Resources and Environment, University of Chinese Academy of Sciences, Beijing 100049, China
}

\begin{abstract}
Swidden agriculture is by far the dominant land use system in the uplands of Southeast Asia (SEA), as well as other tropical regions, which plays an important role in the implementation of Reducing Emissions from Deforestation and Forest Degradation (REDD) of United Nations. To our knowledge, the long-term inter-annual area of newly burned plots (NBP) of swidden agriculture in mainland Southeast Asia is still not available, let alone in the whole tropics. With the strengthening regional geo-economic cooperation in SEA, swidden agriculture has experienced and/or is still experiencing extensive and drastic transformations into other diverse market-oriented land use types since the 1990s. In this study, high-level surface reflectance products of Landsat 4/5/7/8 family sensors including Thematic Mapper (TM), Enhanced Thematic Mapper Plus $(\mathrm{ETM}+)$ and Operational Land Imager (OLI) acquired in March, April and May of each year between 1988 and 2016 were firstly utilized to detect and monitor the extent and area of NBP of swidden agriculture with multiple thresholds of four commonly-used vegetation indices, namely the Normalized Difference Vegetation Index (NDVI), Normalized Difference Moisture Index (NDMI), Normalized Burn Ratio (NBR) and Soil Adjusted Vegetation Index (SAVI), in combination with local phenological features of swiddening and topographical data. The results showed that: (1) an annual average of $6.08 \times 10^{4}$ $\mathrm{km}^{2}$ of NBP of swidden agriculture, or $3.15 \%$ of the total land area of MSEA, were estimated in the past nearly three decades. (2) Annual NBP were primarily distributed in four major geomorphic units including the Central Range of Hills, Northern Mountainous Region, Western Myanmar Hills, and Annamite Chain. (3) A decadal average analysis indicated that the NBP of swidden agriculture opened year by year declined as a whole, especially after 2010 , merely with an average of $5.23 \times 10^{4} \mathrm{~km}^{2}$. (4) The top ten provincial administrative units in Cambodia, Laos, Myanmar, Thailand and Vietnam, which consistently accounted for over $90 \%$ of the newly opened swiddens of each country, showed distinct fluctuations in using
\end{abstract}

Received: 2017-06-07 Accepted: 2018-01-21

Foundation: National Natural Science Foundation of China, No.41301090

Author: Li Peng (1984-), PhD and Associate Professor, specialized in remote sensing of natural resources, land use and cover changes. E-mail: lip@igsnrr.ac.cn; https://orcid.org/0000-0002-0849-5955

"Corresponding author: Feng Zhiming (1963-), PhD and Professor, specialized in regional sustainable development and efficient utilization of resources. E-mail: fengzm@igsnrr.ac.cn 
slash-and-burn practices in the last decades. The Landsat-based $(30 \mathrm{~m})$ reconstructed 29-year longitudinal updated maps (including extent and area) of the NBP of swidden agriculture may contribute to REDD and local livelihood related studies in Continental Southeast Asia. Our study further demonstrated that the multiple vegetative indices thresholds approach holds great potential in detecting swidden agriculture in tropical mountainous regions.

Keywords: swidden agriculture; phenology; newly-burned plots (NBP); Landsat; Montane Mainland Southeast Asia (MMSEA)

\section{Introduction}

Almost 300-500 million upland farmers from over 60 countries in the tropics practice swidden agriculture in the mountainous and hilly regions of Latin America, Central Africa and South/Southeast Asia (Goldammer, 1988; Brady, 1996; van Vliet et al., 2012; Li et al., 2014). Because swidden agriculture involves quasi-periodic slashing and burning of natural and secondary vegetation in the same place (Li et al., 2014), deforestation and forest degradation are the major concerns to global environmental consequences (Achard et al., 2014; Fox et al., 2014). Southeast Asia (SEA) therefore underwent the highest percentage of deforestation rate and prominent forest degradation (Achard et al., 2002; Corlett, 2005; Stibig et al., 2014). Rainforest and dry biomes in mainland Southeast Asia (MSEA) are seriously impacted by the prevailing slash and burn tactics, which raise severe soil erosion and water quality decline (Gupta, 2005; Ziegler et al., 2009; Zwartendijk et al., 2017). Additionally, swidden agriculture is either shortened in the fallow length (Li et al., 2014; Liao et al., 2015) or replaced by other intensified land uses (Ziegler et al., 2011; Laurance et al., 2014; Dressler et al., 2016), particularly agriculture and industrial tree plantations (e.g. rubber, teak, and oil palm). The transformation of swidden agriculture exerts different effects on biological diversity (Rerkasem et al., 2009; Laurance et al., 2014), livelihoods and ecosystem services (Dressler et al., 2015, 2016), and causes substantial reductions of aboveground carbon stocks and soil organic carbon stocks (Bruun et al., 2009; Achard et al., 2014). Therefore, the detection and mapping of updated and historical information of swidden agriculture with remotely sensed data is of great significance to scientific community and serves as prerequisite data basis for swiddening related impacts research. Besides, several recent programmes or initiatives of global influence, such as the United Nations Collaborative Programme on Reducing Emissions from Deforestation and Forest Degradation (or UN-REDD) in Developing Countries, the Belt and Road Initiative (BRI), and the Sustainable Development Goals (SDGs) also call for enhancing mountainous problems research to promote poverty eradication, rainforests protection and regional prosperity.

Swidden agriculture is a dominant land use type in the tropics characterized by its diversity, complexity and dynamics (Padoch et al., 2007; Schmidt-Vogt et al., 2009). It hence brings about much difficulty in swidden agriculture monitoring with remote sensing data (Messerli et al., 2009; Cummings et al., 2017). Currently, there is still a surprising lack of global historical fundamental geographical data of swidden agriculture (Padoch et al., 2007; Schmidt-Vogt et al., 2009). With the strengthening regional economic cooperation in SEA, swidden agriculture has experienced drastic transformations into other diverse market-oriented land use types since the 1990s (Dressler et al., 2016). However, there is very limited information on the basic geographical and demographic data of swidden agriculture 
(Mertz et al., 2009; Schmidt-Vogt et al., 2009), especially in the mainland part (Li et al., 2016). Recently, a landscape mosaics approach was developed to quantify swidden agriculture in Laos (Messerli et al., 2009; Hett et al., 2012). Then, a modified landscape metrics approach based on Moderate Resolution Imaging Spectroradiometer (MODIS) time-series products was also developed to overcome the dependency on the availability of existing land cover data (Hurni et al., 2013, 2013). It is important to note that the above-mentioned swidden agriculture monitoring approaches either rely on existing land cover inventories or use coarse spatial resolution data, such as MODIS $(250 \mathrm{~m})$. The existing land cover data neglect the land use changes information of a region (Hurni et al., 2013) and cannot meet the needs of science and policy researchers in a timely manner. In addition, coarser spatial resolution data usually lead to misclassification and omission as swidden agriculture normally have a small area less than $0.01 \mathrm{~km}^{2}$ (Padoch et al., 2007). Therefore, it requires timely and updated geospatial datasets of newly-burned plots (NBP) of swidden agriculture at finer spatial and improved temporal resolution (Cummings et al., 2017).

Lately, we have developed an approach that takes advantage of multiple spectral bands including the visible, near-infrared (NIR), and shortwave-infrared (SWIR) of Landsat-8 Operational Land Imager (OLI) sensor to generate the first map of swidden agriculture in mainland Southeast Asia and Yunnan Province, China (Li et al., 2016). This approach is based on the unique phenological features of swidden agriculture, i.e., swiddening involves quasi-periodic slashing and burning of natural and secondary vegetation in the same place during March and April every certain years (Li et al., 2014; Liao et al., 2015). The NBP of swidden agriculture are a mixture of felled, dried, and burned vegetation (with reduced moisture content) and exposed (or burned) soil during the peak of dry season. An integrated algorithm based on four vegetation indices, including the Normalized Difference Vegetation Index (NDVI) (Tucker et al., 1986), Normalized Difference Moisture Index (NDMI) (Vogelmann et al., 1988), Normalized Burn Ratio (NBR) (García et al., 1991) and Soil Adjusted Vegetation Index (SAVI) (Huete, 1988), was developed to identify and track those imaging pixels that experienced slashing, drying and burning over time. NDVI and NBR are sensitive to sparse canopy cover (e.g. swidden agriculture) while saturate in case of moderate and dense canopy (e.g. evergreen forests) (Gamon et al., 1995; Fernández-Manso et al., 2016). However, NDMI continues to reflect changes in vegetation moisture content at dense canopy cover (Jackson et al., 2004) and SAVI considerably eliminated soil-induced variations and reduced the saturation effect (Huete, 1988; Huete et al., 1997). Unlike other landscape ecology based approaches that primarily use existing land cover data, the Landsat-based multi-step threshold algorithm combines vegetation indices that are sensitive to changes in the vegetation canopy, land surface moisture, and exposed soils. The usage of Landsat intraand inter-annual images for reconstructing the change trajectories of land use has become a novel research trend (Dong et al., 2016; Dutrieux et al., 2016; Huang et al., 2017), since the free access to Landsat imagery (Woodcock et al., 2008). To our knowledge, no study has applied the intra- and inter-annual Landsat data during the dry season to delineate the newly-burned swidden in the tropics.

In this study, we used our recently reported algorithm to generate the 29-year longitudinal maps of the NBP of swidden agriculture in MMSEA with Landsat historical data products during 1988-2016. The objective is twofold: (1) to generate time-series datasets of NBP of 
swidden agriculture at 30-m spatial resolution, using annual Landsat-derived vegetation indices (NDVI, SAVI, NDMI and NBR) products, and (2) to analyze annual area changes of the NBP of swidden agriculture at provincial (top ten), national (Cambodia, Laos, Myanmar, Thailand and Vietnam) and regional (MSEA) levels. The nearly three decadal resultant maps of the NBP of swidden agriculture in this study could be used to support rural livelihoods improvement, environmental effects evaluation, biodiversity conservation and carbon stocks estimations as basic data source. If the multiple vegetation indices thresholds approach is feasible, then it can be expandable for swiddening monitoring in tropical mountainous regions.

\section{Materials and methods}

\subsection{Study area}

Mainland Southeast Asia (MSEA), also known as Continental Southeast Asia (Figure 1), is a subregion of Southeast Asia which comprises Cambodia, Laos, Myanmar, Thailand, and Vietnam (Chuan, 2005). The region has a tropical monsoon climate featured by greater seasonality, more extremes in both temperature and precipitation, and more pronounced dry spells per year (Chuan, 2005). In the regard of seasonality, MSEA has a cool-dry season from November to February, hot-dry season (March-April), and rainy season between May and October. The dry season (northeast monsoon) is characterized by low cloud cover with less than $20 \mathrm{~mm}$ of rainfall per month. The climate condition not only facilitates the felling, drying, burning of household-based swidden agriculture in this duration, but also contributes to larger acquisition probabilities for Landsat observations with low cloud cover threshold, say, less than or equal to 30\% (Li et al., 2018; Xiao et al., 2018).

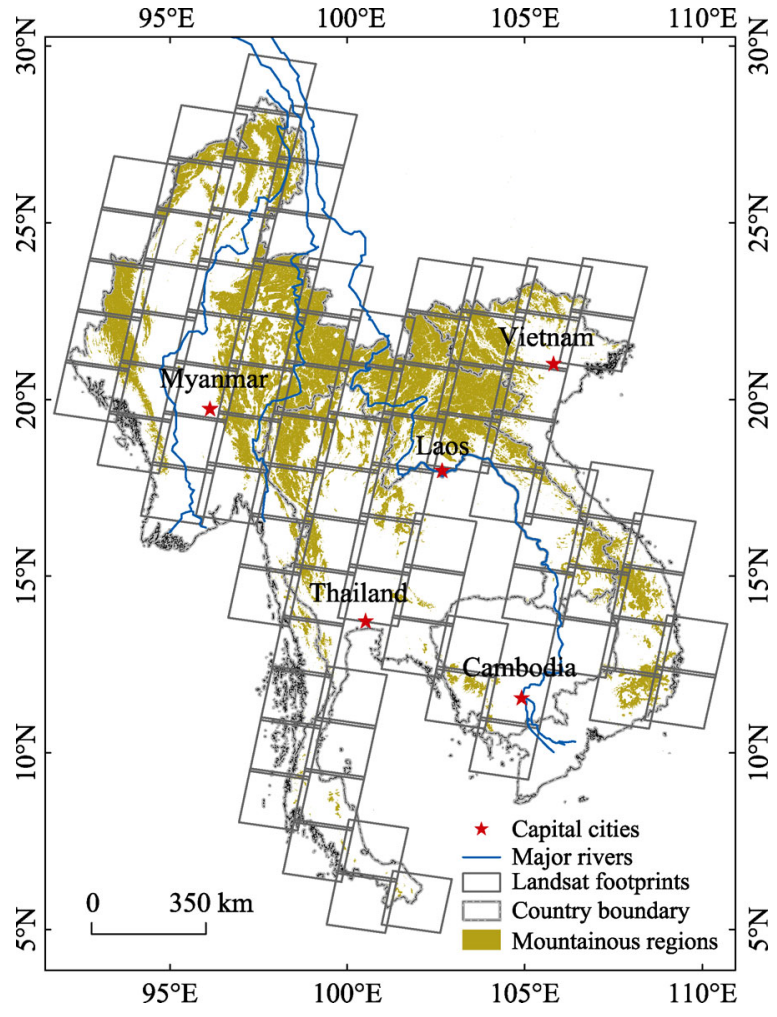

Figure 1 The location map of mainland Southeast Asia (MSEA)

Note: The dark yellow part refers to the redefined mountainous area (or the Redefined MMSEA) covered by 91 Landsat footprints (Path/Row)

Montane Mainland Southeast Asia (MMSEA), or the mountainous regions of MSEA, usually refers to the upland area over $300 \mathrm{~m}$ above sea-level (asl) (Ziegler et al., 2009; Fox et al., 2014). MMSEA normally consists of most parts of Northern Mountainous Region, Western Myanmar Hills, Central Range of Hills (including Shan Highland, Hills of Northern Thailand and Laos, Tenasserim Hills, and Central Highland of Malay Peninsula), Elephant 
and Cardamom Hills, and Annamite Chain (Gupta, 2005). Also, MMSEA is an important part of Zomia, a geographical term referring to the huge mass historically beyond the control of neighboring powerful governments (Van Schendel, 2002; Michaud, 2010). In the uplands, acrisols are the dominated soil types which limit grain output due to high acidity, low fertility, and erosion proneness (Dudal, 2005). Hence, swidden agriculture with short-term fallow cycles is still very common, but experiencing rapid transformation into other acid-tolerant commercial plantations, such as rubber, banana and oil palm (Dudal, 2005). In this study, a redefined mountainous area of MSEA (hereinafter refers as the Redefined MMSEA, see Figure 1) comprises the land with different parametrization of elevational and slope gradient as well as local relief based on the Mountain Research Initiative typology proposed by the United Nations Environment Programme World Conservation Monitoring Center (UNEP-WCMC) (Kapos et al., 2000). The introduction of topographical data (especially the local elevation range) was to reduce the spectral noise effects of permanent farmland and the corresponding human settlements on the detection of swidden agriculture. For more information about the defining process, one can refer to our previous study (Li et al., 2016).

MMSEA used to be the habitat of large, continuous tracts of natural forests (Corlett, $2005)$, which comprise evergreen mountain forests ( $>1000 \mathrm{~m}$ asl), evergreen lowland forests $(<1000 \mathrm{~m}$ asl), mixed deciduous forests, and fragmented and degraded evergreen forest cover (Stibig et al., 2004, 2007). It also occupies the largest proportion of the remaining tropical forests in MSEA (Rerkasem et al., 2009). Around 2010, Cambodia, Laos, Myanmar and Vietnam became the partner countries of the UN-REDD programme in developing countries launched in 2008. Forest-dwelling people include the various and diverse ethnic groups (e.g. Akha, Chin, Hmong-Mien and Shan, etc.), and have been extensively practicing traditional subsistence agriculture (swidden farming) for ages. This traditional farming system therefore remains a dominant land use category in MMSEA (Fox et al., 2005; Schmidt-Vogt et al., 2009). In the past decades, under the pressure of population growth, economic development, and national ecological conservation policies, swidden agriculture has undergone extensive transformations, including conversion into cash-crops (rubber, sugar cane, and banana etcetera) cultivation and shortened fallow periods (Cairns, 2015).

\subsection{Landsat data and vegetation indices products}

Standard high-level surface reflectance products of Landsat Thematic Mapper (TM), Enhanced Thematic Mapper Plus (ETM+) and OLI were ordered, bulk-processed, freely downloaded from the United States Geological Survey (USGS) Earth Resources Observation and Science (EROS) Center Science Processing Architecture (ESPA) (https://espa.cr.usgs.gov/). EROS ESPA provides a number of data application options, including the source products (original input Level 1 products and metadata), top of atmosphere (TOA) reflectance, surface reflectance, $\mathrm{C}$ version function of mask (CFmask), and surface reflectance-based spectral indices, etcetera (USGS, 2016). After June 2, 2017, Landsat Collection 1 Higher-Level data products do not include CFMask processing but provide equivalent pixel-based information in the quality assessment (QA) band. Surface reflectance data are generated from the Landsat Ecosystem Disturbance Adaptive Processing System (LEDAPS) (Masek et al., 2006). CFmask bands, derived from TOA reflectance data, consist of the identification of cloud, cloud shadow, snow/ice and water (Zhu et al., 2012). 
Surface reflectance calculated spectral indices comprise the products of NDVI, SAVI, NDMI, NBR, and other three vegetation indices. In this study, the four forenamed spectral indices were selected to detect NBP of swidden agriculture (pixels), and the CFmask bands were used to exclude the cloud and cloud shadow pixels. The equations are given as follows:

$$
\begin{gathered}
N D V I=\left(\rho_{\text {NIR }}-\rho_{\text {Red }}\right) /\left(\rho_{\text {NIR }}+\rho_{\text {Red }}\right) \\
\text { SAVI }=(1+L)\left(\rho_{\text {NIR }}-\rho_{\text {Red }}\right) /\left(\rho_{\text {NIR }}+\rho_{\text {Red }}+L\right) \\
N D M I=\left(\rho_{\text {NIR }}-\rho_{\text {SWIR } 1}\right) /\left(\rho_{\text {NIR }}+\rho_{\text {SWIR } 1}\right) \\
N B R=\left(\rho_{\text {NIR }}-\rho_{\text {SWIR2 } 2}\right) /\left(\rho_{\text {NIR }}+\rho_{\text {SWIR } 2}\right)
\end{gathered}
$$

where $\rho_{\text {Red }}, \rho_{\text {NIR }}, \rho_{S W I R 1}$ and $\rho_{S W I R 2}$ refer to surface reflectance values of the Red, NIR, SWIR1 and SWIR2 spectral bands of Landsat 4/5/7/8 TM, ETM+, and OLI sensors, respectively. The constant, $L$, represents the parameter of soil brightness correction. The $L$ value varies from zero for higher vegetation densities to 1.0 for lower vegetation condition. Typically, an $L$ value of 0.5 is the default setting for most situations, normally indicating intermediate vegetation densities.

Because the newly-burned swidden fields were primarily kept sun/air dried and intensively burned between March and April each year (Li et al., 2014), Landsat TM, ETM+, and OLI images acquired over MMSEA during the hot-dry season from 1988 to 2016 were all seriously selected without considering the issues of cloud coverage and Scan Line Corrector (SLC) failure for targeted pixels extraction. Besides, Landsat images gathered in May (post-burn stage and before cropping of rainy season) were also collected as alternate data sources due to data unavailability in the optimum period, i.e., from March to April. According to the Redefined MMSEA, 91 Landsat path/row (PR) coordinates cover the study area (Figure 1), with a total of 16,647 qualified scenes acquired during the past 29 years. However, 58 Landsat scenes (about $0.3 \%$ ) could not be processed into surface reflectance data due to missing auxiliary input data and/or necessary thermal data (U.S. Geological Survey, 2016). The left 16,589 scenes used in this study, consisted of 9115 TM scenes (or 54.9\%), 5,729 ETM+ scenes (or 34.6\%, including 4542 ETM+ SLC-off scenes), and 1745 OLI scenes (or $10.5 \%$ ). Among the 16,589 scenes, $50.1 \%$ of them had less than or equal to $30 \%$ cloud cover. More specifically, there were $28.8 \%$ of the scenes less than or equal to $10 \%$ cloud cover, $11.9 \%$ of the scenes greater than $10 \%$ and less than or equal to $20 \%$ cloud cover, and the remaining $9.4 \%$ scenes greater than $20 \%$ and less than or equal to $30 \%$ cloud cover. In the regard of the monthly number of scenes, there were 33.5\% scenes in March, 34.2\% scenes in April, and 32.3\% scenes in May, respectively.

This study aims to extract annual average NBP area of swiddening pixels to the maximum extent based on the available Landsat images at 8- to 16-day interval. Although the phenological arrangement information of swidden agriculture during the dry season is typically known to scientific community, both the degrees of sun/air drying and the specific dates for man-made burning are not clear for imagery users. It therefore may not fully obtain the annually maximum extent and area of swidden agriculture using satellite images observed at only a single point in time (Hurni et al., 2013). One major improvement to this issue is to utilize all the Landsat imagery observed during the hot-dry season with the purpose of obtaining the utmost accurate spatial pattern of newly-burned swidden as far as possible. 


\subsection{The algorithm for detecting newly-burned plots (NBP) of swiddening fields in MSEA}

Swidden agriculture detection with remote sensing techniques is always challenged due to its dynamics and complexity. For a given year, this traditional farming system usually displays various landscapes, such as newly-burned plots (including those under drying and freshly-burned), cultivated fields, and fallows (normally secondary forests) at different stages. In a previous study, swidden agriculture including the NBP of swidden agriculture and variously-aged fallows were detected, in a Time-for-Space substitution manner, using a multi-step threshold (MST) method with Landsat OLI derived vegetation indices (NDVI, SAVI, NDMI and NBR) in the Redefined MMSEA (Li et al., 2016). Because newly swidden fields were cleared during the hot dry season each year, in this study, swidden agriculture from 1988 to 2016 were consistently detected and mapped from the perspective of NBP by means of multiple spectral indices (NDVI, SAVI, NDMI and NBR) thresholds (hereinafter refer as MSIT). Specifically, the thresholds criteria comprise NDVI greater than or equal to 0.10 , and SAVI, NDMI and NBR simultaneously less than or equal to 0.20 , respectively. All the pixels of cloud and cloud shadow were excluded accordingly. The actual NBP of each image was extracted using the MSIT algorithm by intersecting with the Redefined MMSEA, followed by combining all potential NBP extracted from March to May each year into an annual NBP composite. Finally, a total of 29 resultant annual-maps of newly opened swidden over MMSEA were developed for the first time. Then, the spatial and temporal change patterns of NBP of swidden agriculture were analyzed for each country. The aforementioned data calculation and analysis were batch-processed based on Python programming language with ArcPy under ArcGIS 10.2 platform.

\section{Results and analysis}

\subsection{Annual extent and area of the NBP of swiddening in Montane Mainland South- east Asia (MMSEA) during 1988-2016}

Figure 2 shows the 29-year longitudinal maps of the NBP of swidden agriculture in MSEA during 1988-2016. In the past nearly three decades, an annual average area of $6.08 \times 10^{4} \mathrm{~km}^{2}$ of swidden plots, or $3.15 \%$ of the total land area, was newly opened each year in the uplands. Local highland ethnic groups (e.g. Akha, Chin, Hmong-Mien and Shan) usually practice the slash and burn tactics for multiple livelihoods purposes including agriculture (e.g. upland or dry rice and Job's tears), forestry (e.g. rubber, teak and eucalyptus), and agroforestry (e.g. intercropping) in MMSEA.

Temporally, the largest and smallest areas of the NBP of swiddening occurred in 2007 up to $9.19 \times 10^{4} \mathrm{~km}^{2}$, or $4.75 \%$ of territory area of MSEA and, while in 2011 merely $3.94 \times 10^{4}$ $\mathrm{km}^{2}$, or $2.04 \%$ of MSEA (Figure 3), respectively. Table 1 gives a full numeric list of the maximum and minimum areas and the corresponding area proportions of newly opened swiddens in each country during the same period. The maximum NBP area in Vietnam, Laos and Cambodia happened in the mid-2000s while those of Myanmar and Thailand appeared in the late 1990s. However, the occurrence years of annual minimum NBP area of swidden agriculture for MSEA countries were not fixed (Figure 3). 


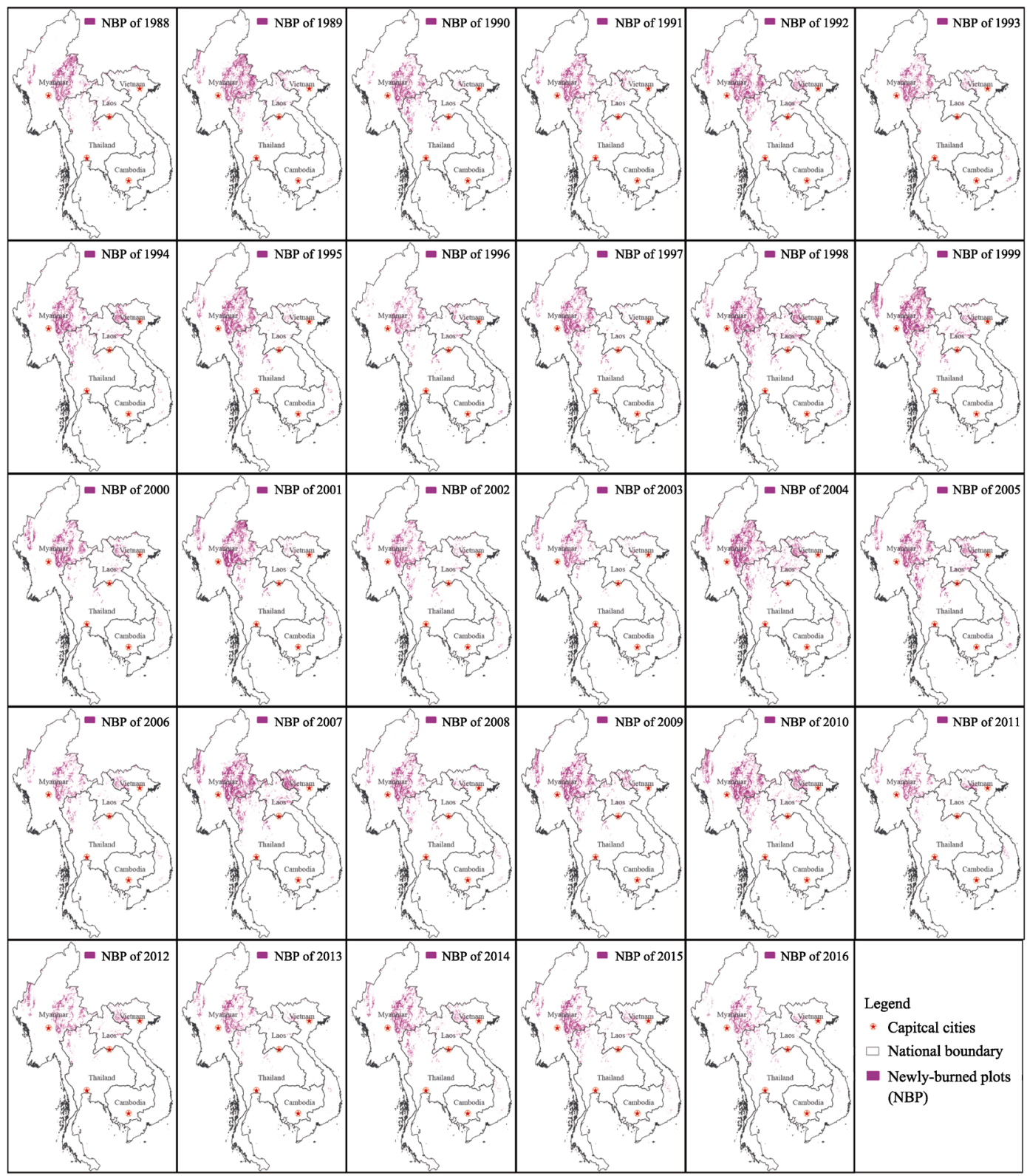

Figure 2 The twenty-nine 30-m resolution longitudinal maps of the newly-burned plots (NBP) of swidden agriculture derived from the multiple Landsat-based vegetation indices (NDVI, SAVI, NDMI and NBR) thresholds in the redefined MMSEA from 1988 to 2016

Spatially, annual NBP were primarily distributed in four major geomorphic units including the Central Range of Hills, Northern Mountainous Region, Western Myanmar Hills, and Annamite Chain (Figure 2). In addition, the borderlands of Myanmar-Thailand, Vietnam-Laos, and Myanmar and India were also the important locations of swidden agriculture. The resultant distributions of annual NBP were much close to those of Schmidt-Vogt's study (2009). Of the five countries in MSEA, Myanmar (particularly Shan Plateau and Arakan Yoma) had the largest proportion of annual average NBP area of swiddening $(67.60 \%)$, followed by Thailand (especially northern part) with $13.28 \%$, Vietnam (especially northwestern 

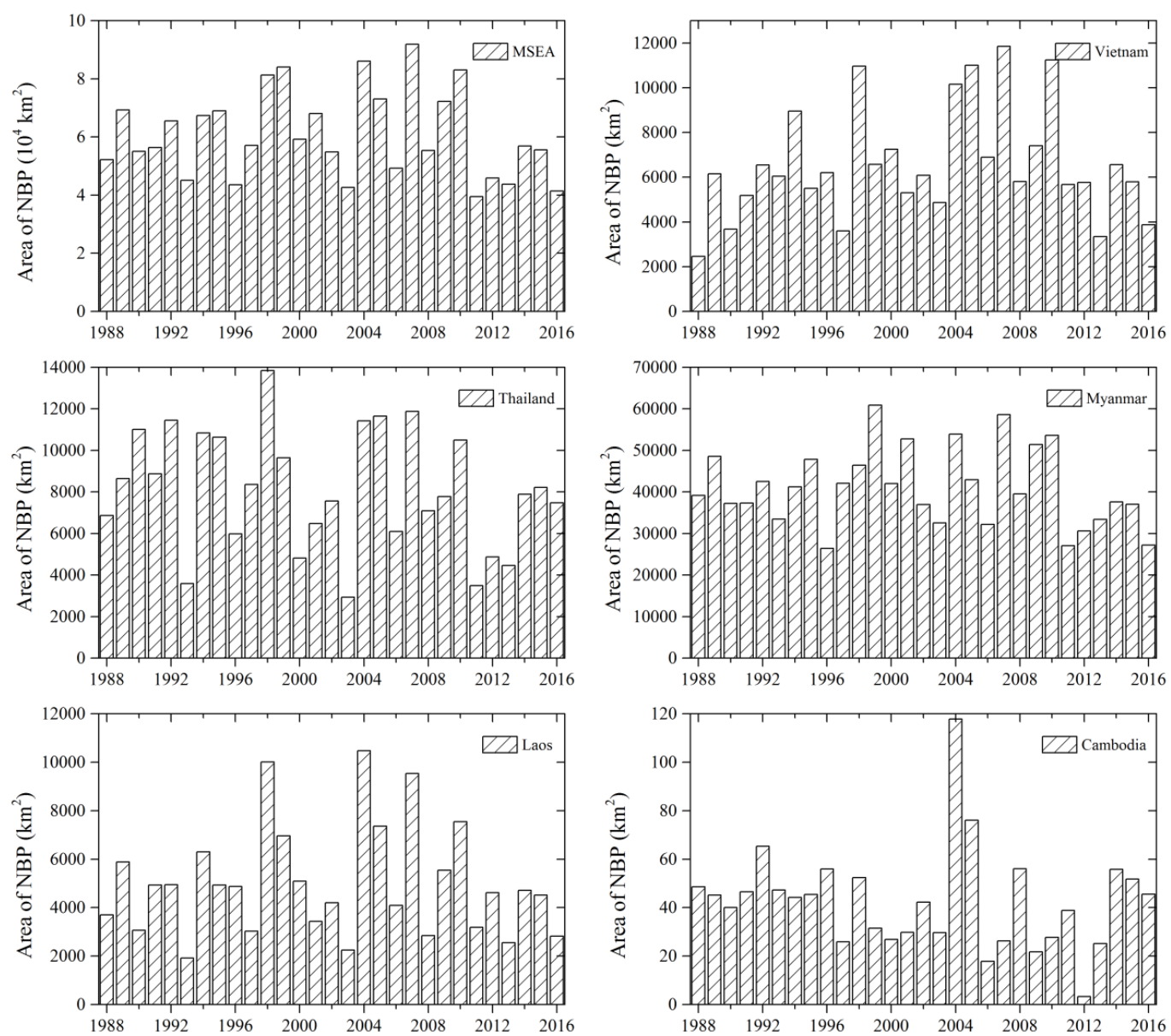

Figure 3 Annual average area of the newly-burned plots (NBP) of swidden agriculture in Cambodia, Laos, Myanmar, Thailand, Vietnam and the whole Montane Mainland Southeast Asia during 1988-2016

Table 1 The maximum and minimum area sizes of the newly-burned plots (NBP) of swiddening and the corresponding proportions of total land area and the related occurrence years in Cambodia, Laos, Myanmar, Thailand, Vietnam and MSEA $\left(10^{4} \mathrm{~km}^{2}\right.$ and \%)

\begin{tabular}{lcccccc}
\hline & \multicolumn{3}{c}{ Maximum area } & \multicolumn{3}{c}{ Minimum area } \\
\cline { 2 - 7 } & Quantity & Proportion & Year & Quantity & Proportion & Year \\
\hline MSEA & 9.19 & 4.75 & 2007 & 3.94 & 2.04 & 2011 \\
Cambodia & 0.01 & 0.07 & 2004 & - & - & $2012 *$ \\
Laos & 1.05 & 4.42 & 2004 & 0.19 & 0.81 & 1993 \\
Myanmar & 6.08 & 9.00 & 1999 & 2.64 & 3.90 & 1996 \\
Thailand & 1.38 & 2.70 & 1998 & 0.29 & 0.57 & 2003 \\
Vietnam & 1.18 & 3.59 & 2007 & 0.25 & 0.75 & 1988 \\
\hline
\end{tabular}

Note: The smallest area of newly-burned swidden in Cambodia was approximately $3.32 \mathrm{~km}^{2}$ in 2012 .

part) with $10.81 \%$, Laos (especially northern part) with $8.24 \%$ and Cambodia (especially northeastern part) merely with $0.07 \%$, respectively. Earlier study showed that there were about $4500 \mathrm{~km}^{2}$ annually for swiddening in Laos (Hansen, 1998), while our annual average 
estimate was $5010 \mathrm{~km}^{2}$. It should be noted that the total area of swidden agriculture in MSEA countries would be much larger if swidden fallows at different stages were taken into consideration (Hansen, 1998; Messerli et al., 2009; Li et al., 2016).

National (quasi-) decadal average area of newly opened swiddens and the related area proportions were listed in Table 2. In the past nearly three decades, the NBP area of swiddening opened year by year declined as a whole (Table 2 and Figure 9a), especially after 2010 , merely with mean area of $5.23 \times 10^{4} \mathrm{~km}^{2}$. This declining trend of the NBP of swidden agriculture in MSEA can be explained because of governmental awareness and international endeavor, such as the opium-replacement policy in the 1980s (Cohen, 2009; Tian et al., 2011), the alternative development in the 1990s and the recent UN-REDD Programme (Fox et al., 2014). For example, Lao government used to increase the area of rubber plantations after 2003 through individuals, private- and state-sectors entities to respond to high rubber prices at that time (Manivong et al., 2008), so as to curb opium poppy cultivation. However, the extensive rubber plantation expansion didn't last quite long until 2010 due to the emerging issues in land grabbing especially in southern Laos. Then, Lao government terminated the permission of new establishment of rubber plantation across the country. In addition, in 1999, Myanmar and local authorities decided to engage in a 15-year plan to eliminate opium poppy by the year 2014 (Tian et al., 2011).

Table 2 The (quasi-) decadal average area and the related area proportions of the newly-burned plots (NBP) of swidden agriculture in Cambodia, Laos, Myanmar, Thailand, Vietnam and MSEA $\left(10^{4} \mathrm{~km}^{2}\right.$ and \%)

\begin{tabular}{lcccccc}
\hline & & (Quasi-) Decadal average area & & \multicolumn{2}{c}{$\begin{array}{c}\text { Annual aver- } \\
\text { age area }\end{array}$} & $\begin{array}{c}\text { Proportion of } \\
\text { total land area }\end{array}$ \\
\cline { 2 - 7 } & $1980 \mathrm{~s}$ & $1990 \mathrm{~s}$ & $2000 \mathrm{~s}$ & $2010 \mathrm{~s}$ & $1988-2016$ & $\%$ \\
\hline MSEA & 6.08 & 6.24 & 6.52 & 5.23 & 6.08 & 3.15 \\
Cambodia & - & - & - & - & - & 0.02 \\
Laos & 0.48 & 0.51 & 0.55 & 0.43 & 0.50 & 2.12 \\
Myanmar & 4.39 & 4.15 & 4.42 & 3.52 & 4.11 & 6.08 \\
Thailand & 0.78 & 0.94 & 0.78 & 0.67 & 0.81 & 1.57 \\
Vietnam & 0.43 & 0.63 & 0.77 & 0.60 & 0.66 & 2.00 \\
\hline
\end{tabular}

Note: The (quasi-) decadal average area of the NBP in Cambodia were about $45 \mathrm{~km}^{2}$ during 1988-2009 and then reduced to $10 \mathrm{~km}^{2}$ or so in the $2010 \mathrm{~s}$.

Before the early 1990s, MSEA countries with the exception of Thailand suffered from long-term conflict and/or isolation which lead to poor socio-economic progress and slight land surface changes. Afterwards, geo-economic cooperation activities started with the Greater Mekong Subregion economic cooperation program launched in 1992 among MSEA and its neighboring countries (especially China and India) were gradually embarked on to promote regional economic and social development. MSEA therefore experienced extensive and continuous rapid land use and land cover changes due to rapid economic development. In this sense, the annual mean NBP area of swidden agriculture (nearly $6.08 \times 10^{4} \mathrm{~km}^{2}$ ) established in the late 1980s (both 1988 and 1989) can be viewed as the traditional development level of slash-and-burn farming in the past. Not coincidentally, the numerical value was almost equal to the average level of the last 30 years.

Compared with the past development level, however, there still showed obvious area in- 
crement of newly-burned swidden during the 1990s and 2000s (Table 2), both with larger average NBP values of $6.24 \times 10^{4} \mathrm{~km}^{2}$ and $6.52 \times 10^{4} \mathrm{~km}^{2}$, respectively. In the first decade of the 21 st century, more evident expansion of the NBP of swiddening was detected across MSEA due to inadequate central government supervision on land lease and its disordered development. It can be cautiously inferred that the rising of slashing and burning phenomenon has close connection with the expansion of economic crops gardens (e.g. banana, coffee and sugar cane) and tree plantations (for instance, rubber, teak and eucalyptus). It was not until circa 2010 that the central governments of MSEA nations realized the social issues (like land grabbing) and environmental pollutions (e.g. pesticides and fertilizers) of swidden agriculture and slash-and-burn related agroforestry development, and then started to impose restrictions on it. The annual NBP area was the smallest in 2011 and showed a decreasing trend accordingly. For example, upland households are simply permitted to reuse the already-opened swidden plots and prohibited to reclaim new land parcels in Laos according to our field investigation in 2016. In comparison, there were only two years (1998 and 1999) with an annual area larger than $7.00 \times 10^{4} \mathrm{~km}^{2}$ in the $1990 \mathrm{~s}$, while the corresponding number of years increased to four, namely 2004, 2005, 2007 and 2009 in the 2000s, and only one in the $2010 \mathrm{~s}$, that is 2010 . There were basically similar temporal changes at the country level with the exception of Vietnam, which was characterized by more frequent usage of the slash-and-burn practice in the 1990s and 2000s (Table 2). A flux of formally lowland populated people who migrated into the uplands to practice swidden agriculture during this period accelerated its expansion especially in Central Highlands and the northwest part of Vietnam.

\subsection{National differences in annual area and spatial pattern of the newly-burned plots (NBP) of swiddening in MMSEA during 1988-2016}

As it showed above, the spatial and temporal dynamics of the newly-burned plots of swidden agriculture varied dramatically at national level as well as provincial level. Because the five countries have 14 to 78 provinces regardless of the size of land area, then the top ten provinces of annual average NBP area in each country were further selected to clearly illustrate the annual provincial variations. The area proportions of the newly-burned plots of swidden agriculture for these provinces in Cambodia, Laos, Myanmar, Thailand and Vietnam were all consistently larger than $90 \%$. Therefore, the provincial level analyses can clearly reflect the spatial patterns of each country in the past decades as a whole.

\subsubsection{Cambodia}

The top ten provinces of larger annual average area of the NBP in Cambodia during 1988-2016 in sequence were Mondulkiri, Ratanakiri, Koh Kong, Preah Sihanouk, Pursat, Kampot, Battambang, Pailin, Kampong Speu and Preah Vihear, respectively (Figure 4). The total average NBP area of the top ten provinces accounted for up to $99.8 \%$ in this country. Of these provinces, Mondulkiri and Ratanakiri in northeastern Cambodia, dominated by highlands at altitudes from $200 \mathrm{~m}$ to $1000 \mathrm{~m}$, had $66.2 \%$ and $9.5 \%$ of the total average area of newly-burned plots of swidden agriculture, respectively. Among them, Mondulkiri Province had the maximum annual average NBP of swidden farming, about $28.31 \mathrm{~km}^{2}$. Our calculation results of the annual average NBP area were different from the qualitative estimates 
reported earlier, as swidden agriculture is mainly found in Ratanakiri Province (Schmidt-Vogt et al., 2009). The slash-and-burn techniques were typically applied for the expansion of rubber plantation invested by foreign (for example Vietnamese and Chinese) enterprises in these provinces. Besides, seven of them including Koh Kong, Preah Sihanouk, Pursat, Kampot, Battambang, Pailin, and Kampong Speu in the southwestern part of Cambodia, covering the Cardamom and Elephant Mountains with an elevation range of $500-1800 \mathrm{~m}$, accounted for $23.8 \%$ of the total average area of the NBP. Although Mondulkiri Province had the largest percentage of the NBP area in the past nearly three decades, it still displayed a declining trend which was in line with the general development trend of Cambodia (Figure 9b). The first five provinces had the maximum annual average NBP area larger than $7 \mathrm{~km}^{2}$. Among them, Mondulkiri, Koh Kong and Pursat occurred in the mid-2000s, Ratanakiri in the early 2010s and Preah Sihanouk in the late 1980s. Regarding to the occurrence years of minimum annual average values, Mondulkiri, Koh Kong and Preah Sihanouk happened in 2012, Ratanakiri in 1990 and Pursat in 1988. From the view of the maximum annual average NBP area (less than $7 \mathrm{~km}^{2}$ ), the changing trends of decadal average in other five provinces were less obvious.

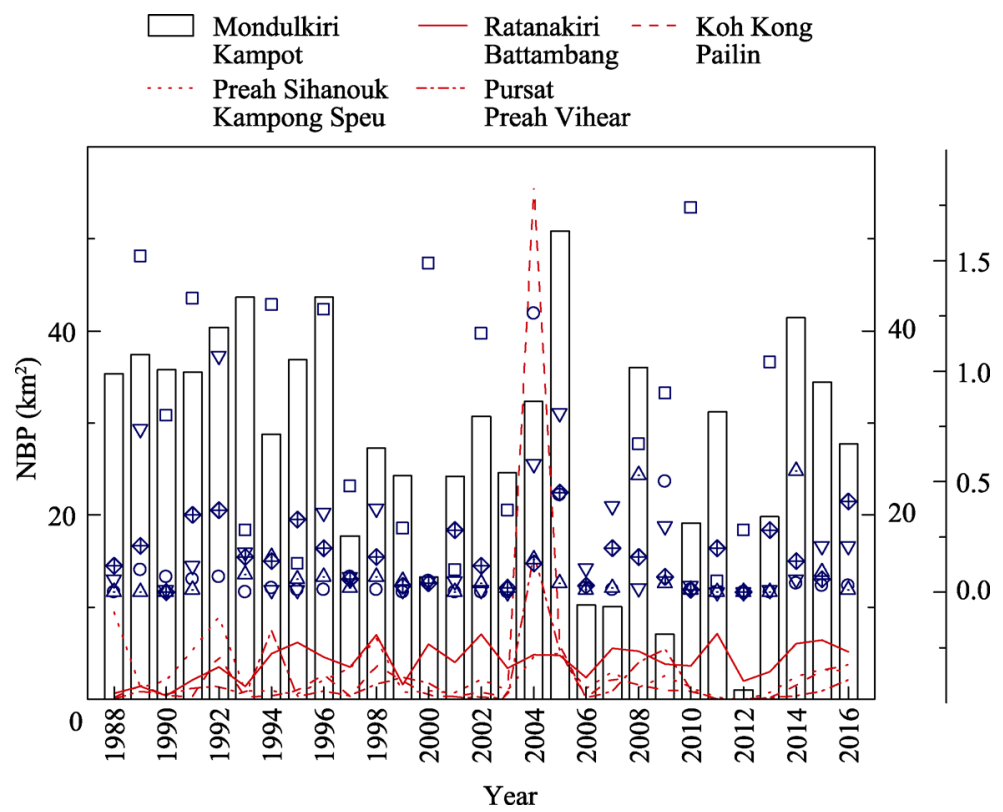

Figure 4 Temporal variations in annual average area of the newly-burned plots (NBP) of swidden agriculture for the top ten provinces in Cambodia during 1988-2016

Note: The province (i.e., Mondulkiri) with the largest NBP area was plotted with histogram (empty), the second to fifth provinces with line (e.g., solid, dashes, dots and dash dot), and the remaining five provinces with scatter in different symbols, respectively.

\subsubsection{Laos}

The top ten provinces of larger annual average area of the NBP in Laos during 1988-2016 in sequence were Louang Phrabang, Xiangkhoang, Phongsali, Houaphan, Oudomxay, Xaignabouri, Louang Namtha, Xaysomboun, Bokeo and Bolikhamxai respectively (Figure 5). The total average NBP area of the top ten provinces accounted for up to $92.2 \%$ in Laos. Of 
these provinces, the eight provinces in northern Laos were all included, accounting for $79.8 \%$, and the other two provinces were located in central Laos, i.e., Xaysomboun and Bolikhamxai, with 20.2\%. Among them, Louang Phrabang Province had the maximum annual average NBP of swidden farming, about $901.46 \mathrm{~km}^{2}$. Therefore, the newly-burned plots of swidden agriculture were primarily distributed in northern Laos during 1988-2016. This vast mountainous region used to be the primary area for opium poppy cultivation. With regard to the inter-annual variability of the NBP area, Laos showed a slightly declined trend at the country level. This can be explained that there were increasingly governmental efforts to prohibit swidden agriculture and opium cultivation throughout the country since the late 1980s. For instance, the upland slash-and-burn farmers (such as Lao Theung and Lao Soung) were resettled in lowlands to cultivate paddy rice as Lao Loum.

However, the variabilities at the provincial level for the ten provinces were particularly different. Six of the ten provinces, including Louang Phrabang, Houaphan, Oudomxay, Louang Namtha, Bokeo and Bolikhamxai, had the maximum annual average NBP area in the mid-2000s, three of them (Xiangkhoang, Phongsali and Xaysomboun) in the late 1990s and one (i.e., Xaignabouri) in 2010. In contrast, with regard to the minimum annual average NBP area, Xiangkhoang, Louang Namtha and Bokeo occurred in the late 1980s, Phongsali, Oudomxay, Xaignabouri and Xaysomboun in the early 1990s, Houaphan in the late 1990s, finally Louang Phrabang and Bolikhamxai in the 2010s. Three provinces including Louang Phrabang, Phongsali and Bolikhamxai showed a declining trend as a whole, while provinces such as XiangKhoang, Houaphan, Oudomxay and Louang Namtha varied just the opposite, and the other three showed slight variations in the past decades (Figure 9c).

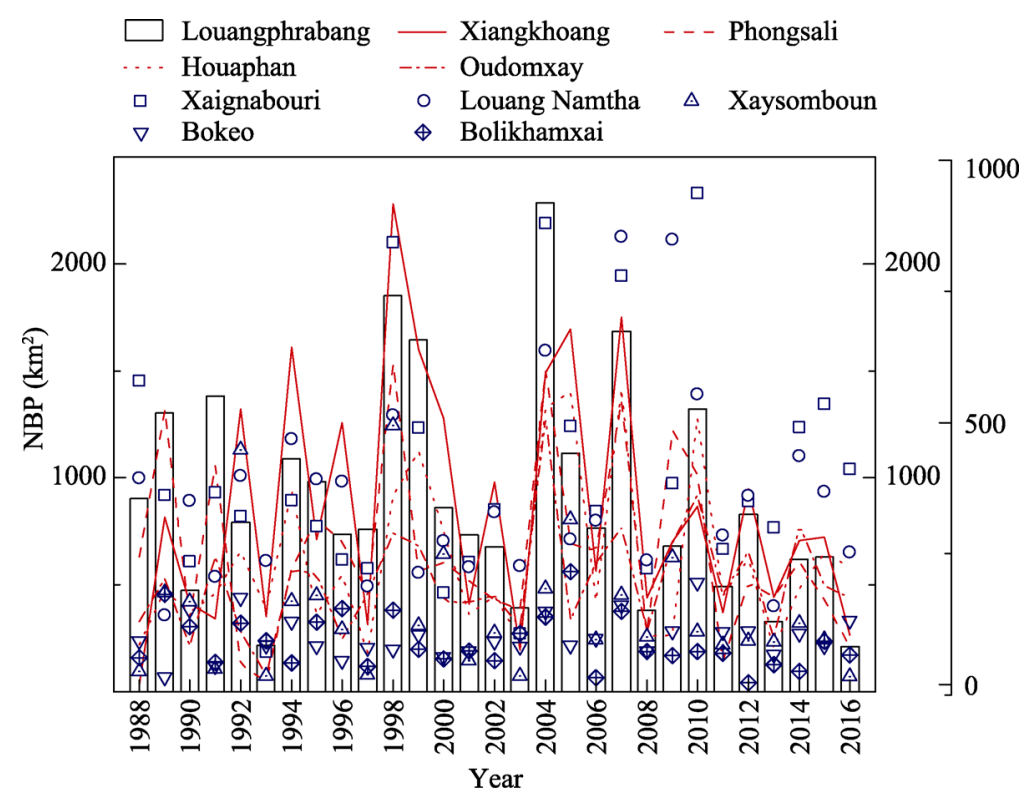

Figure 5 Temporal variations in annual average area of the newly-burned plots (NBP) of swidden agriculture for the top ten provinces in Laos during 1988-2016

Note: The province (i.e., Louang Phrabang) with the largest NBP area was plotted with histogram (empty), the second to fifth provinces with line (e.g., solid, dashes, dots and dash dot), and the remaining five provinces with scatter in different symbols, respectively. 


\subsubsection{Myanmar}

The top ten provincial administrative regions with larger annual average NBP area in Myanmar during 1988-2016 in sequence were Shan State, Chin State, Kayah State, Mandalay Region, Magway Region, Sagaing Region, Kachin State, Kayin State, Rakhine State and Bago Region respectively (Figure 6). Schmidt-Vogt and his colleagues (2009) earlier claimed that swidden agriculture was mainly found in the Karen, Shan, Kachin and Chin States of eastern and northern Myanmar. Our results of the distribution of swidden agriculture in Myanmar were in accordance with that. The total average area of the top ten states and regions accounted for up to $99.9 \%$ in Myanmar. There were four states or provinces with annual average NBP area greater than $1000 \mathrm{~km}^{2}$, i.e., Shan $\left(30,299.22 \mathrm{~km}^{2}\right)$, Chin $(4360.81$ $\mathrm{km}^{2}$ ), Kayah $\left(2321.16 \mathrm{~km}^{2}\right)$ and Mandalay $\left(1455.38 \mathrm{~km}^{2}\right)$, respectively.

With regard to the inter-annual variability of NBP area, Myanmar also showed a slightly declining trend at the country level, although fluctuated year by year (Figure 9d). It should be noted that the maximum annual average NBP area of the ten provincial units all happened between 1999 and 2010. Among them, the first four states or provinces, namely Shan State, Chin State, Kayah State and Mandalay Region, all occurred in 1999, Magway Region in 2010 and the other five in the 2000s. By contrast, the provincial minimum annual average NBP occurred either in the 1990s and the 2010s, half (i.e., Chin State, Magway Region, Sagaing Region, Rakhine State and Bago Region) and half (i.e., Shan State, Kayah State, Mandalay Region, Kachin State and Kayin State). However, the variabilities at the provincial level particularly for the ten provinces were different. Four states in eastern Myanmar including Shan, Kayah, Kachin and Kayin typically showed a declining trend, while the other six states (Chin and Rakhine) or regions (Mandalay, Magway, Sagaing and Bago) varied in an increasing manner. Currently, reasons for the annually dynamic changes in the NBP

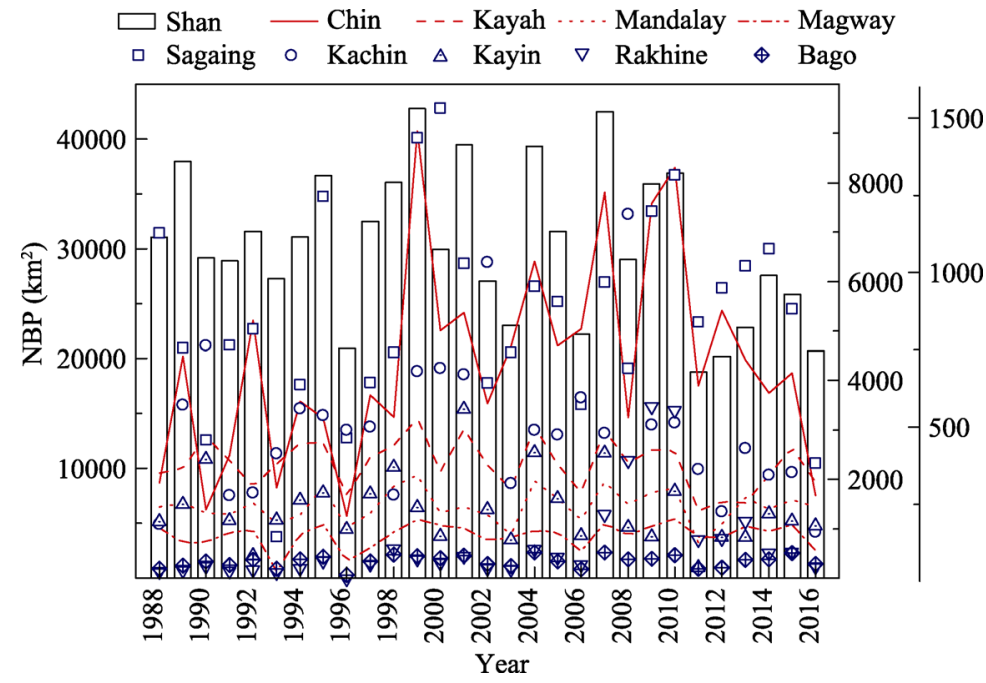

Figure 6 Temporal variations in annual average area of the newly-burned plots (NBP) of swidden agriculture for the top ten provinces in Myanmar during 1988-2016

Note: The state (i.e., Shan) with the largest NBP area was plotted with histogram (empty), the second to fifth provinces with line (e.g. solid, dashes, dots and dash dot), and the remaining five provinces with scatter in different symbols, respectively. 


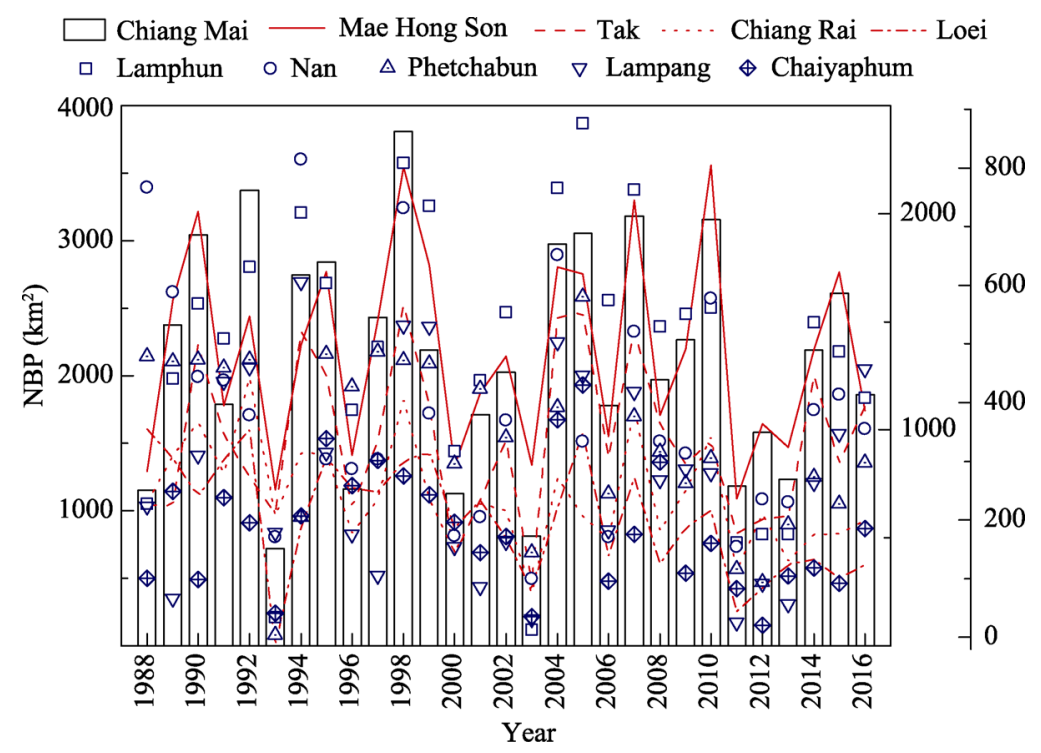

Figure 7 Temporal variations in annual average area of the newly-burned plots (NBP) of swidden agriculture for the top ten provinces in Thailand during 1988-2016

Note: The province (i.e., Chiang Mai) with the largest NBP area was plotted with histogram (empty), the second to fifth provinces with line (e.g., solid, dashes, dots and dash dot), and the remaining five provinces with scatter in different symbols, respectively.

of swidden agriculture in Myanmar are unclear. With regard to the decadal average of NBP area from the 1980s to the 2010s (Figure 9d), Shan state decreased obviously, and Chin State increased during the 2000s, while other eight states or regions varied slightly.

\subsubsection{Thailand}

The top ten provinces with larger annual average NBP area in Thailand during 1988-2016 in sequence were Chiang Mai, Mae Hong Son, Tak, Chiang Rai, Loei, Lamphun, Nan, Phetchabun, Lampang and Chaiyaphum, respectively (Figure 7). Schmidt-Vogt et al. (2009) claimed that swidden cultivation is mainly practiced by ethnic minorities in the northern uplands close to the border with Laos and Myanmar. Our results of the spatial pattern of swidden agriculture were in line with their conclusion. The total average area of the top ten provinces accounted for up to $91.8 \%$ in Thailand. There were only two provinces with annual average NBP area greater than $1000 \mathrm{~km}^{2}$, i.e., Chiang Mai $\left(2150.23 \mathrm{~km}^{2}\right)$ and Mae Hong Son $\left(1360.05 \mathrm{~km}^{2}\right)$. Thailand is variably divided into different sets of regions, the most notable of which are the six-region grouping used in geographic studies, namely Northern Thailand, Northeastern Thailand, Western Thailand, Central Thailand, Eastern Thailand and Southern Thailand. Of these provinces, six of them including Chiang Mai, Mae Hong Son, Chiang Rai, Lamphun, Nan and Lampang were from Northern Thailand, Loei and Chaiyaphum from Northeastern Thailand, Tak and Phetchabun from Western and Central Thailand respectively. The NBP of swiddening opened by the Karen tribe in these provinces were mainly distributed along the Thailand-Myanmar border. The top three provinces (Chiang Mai, Mae Hong Son and Tak) with larger area of NBP as well as Lamphun and Lampang, displayed relatively stable changing trends, while the NBP area of other provinces declined conformably (Figure 9e). Of the ten provinces, Loei and Mae Hong Son had the maximum 
annual average NBP in 1988 and 2010, respectively, Chiang Rai, Nan and Lampang in the early 1990s, Chiang Mai and Tak in 1998, as well as Lamphun, Phetchabun and Chaiyaphum in 2005. In contrast, Chiang Mai, Loei and Phetchabun had the minimum values of annual average NBP in 1993, Tak, Chiang Rai, Lamphun and Nan in 2003, and the last three in the early 2010 s.

\subsubsection{Vietnam}

The top ten provinces with larger annual average NBP area in Vietnam during 1988-2016 in sequence were Son La, Dien Bien Phu, Lai Chau, Ha Giang, Lam Dong, Kon Tum, Gia Lai, Lao Cai, Yen Bai and Cao Bang, respectively (Figure 8). The total average area of the top ten provinces accounted for up to $94.0 \%$ in Vietnam. Of these provinces, five of them including Son La, Dien Bien Phu, Lai Chau, Lao Cai and Yen Bai were from Northwest Vietnam, three provinces of them including Lam Dong, Kon Tum and Gia Lai from Central Highlands and another two from Northeast Vietnam. There were only two provinces with annual average NBP area greater than $1000 \mathrm{~km}^{2}$, i.e., Son La $\left(1997.68 \mathrm{~km}^{2}\right)$ and Dien Bien Phu $\left(1441.55 \mathrm{~km}^{2}\right)$. Just as Vietnam showed a slightly increasing trend of decadal average, the NBP of swiddening in all the ten provinces with the exception of Ha Giang and Cao Bang, two mountainous provinces shared long borderline with China, increased in varying degrees. Among them, for example, Son La Province, with the largest area of NBP, showed a largest growth rate from the 1980 s to the 2010 s, up to over $300 \%$ (Figure $9 \mathrm{f}$ ). For the ten provinces, Son La, Dien Bien Phu, Lam Dong and Gia Lai had the maximum annual NBP area in the mid-2000s, Lai Chau, Ha Giang, Kon Tum and Lao Cai in the early 2010s, as well as Yen Bai in 1994 and Cao Bang in 1989. In contrast, six provinces, namely Son La,

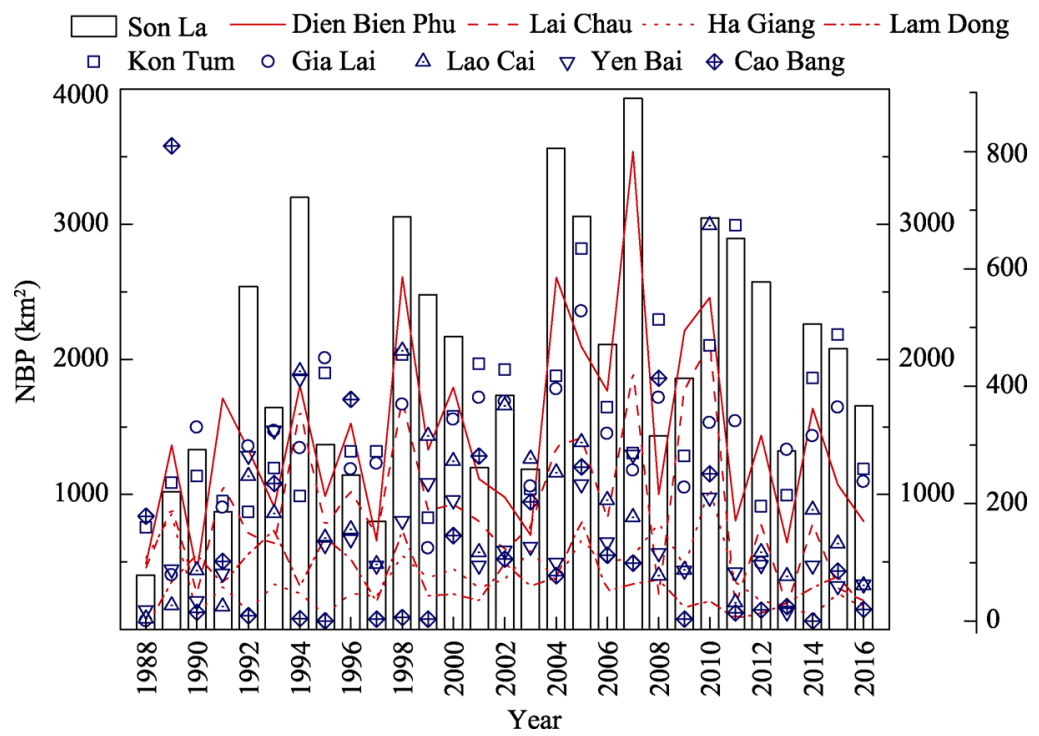

Figure 8 Temporal variations in annual average area of the newly-burned plots (NBP) of swidden agriculture for the top ten provinces in Vietnam during 1988-2016

Note: The province (i.e., Son La) with the largest NBP area was plotted with histogram (empty), the second to fifth provinces with line (e.g., solid, dashes, dots and dash dot), and the remaining five provinces with scatter in different symbols, respectively. 

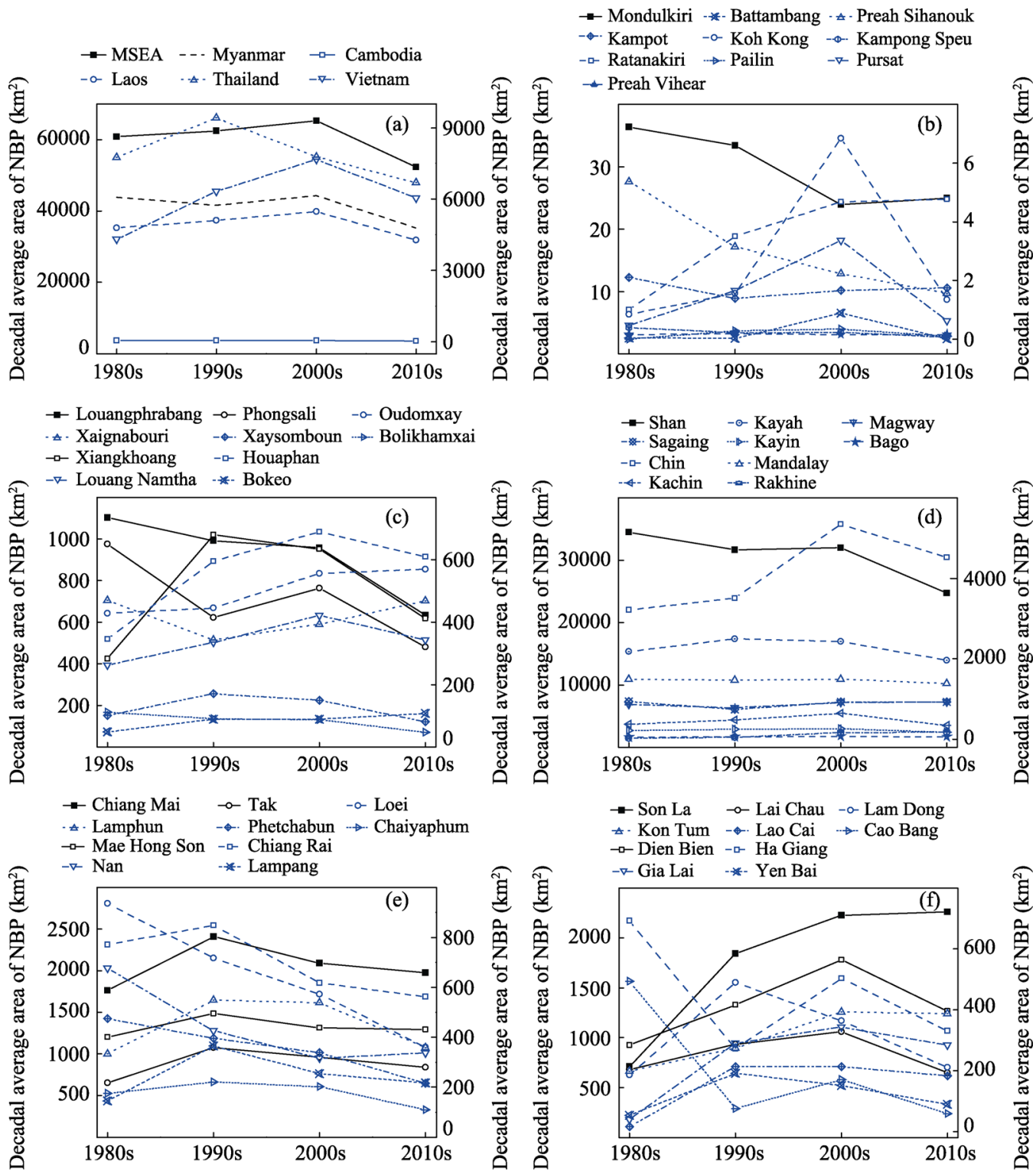

Figure 9 Temporal changes in decadal annual average area of newly-burned plots (NBP) of swidden agriculture at provincial, national and regional levels during 1988-2016

Note: (a) MSEA and the five countries; (b)-(f) refers to the top ten provinces of MSEA countries in an alphabetical order.

Lam Dong, Kon Tum, Gia Lai, Lao Cai and Yen Bai, had the minimum annual average NBP in 1988, Dien Bien Phu and Cao Bang in the early 1990s, and two final ones (Lai Chau and Ha Giang) in the early 2010s. It also further implies the decadal growth trend of newly opened plots of swidden farming.

\section{Conclusions and discussion}

\subsection{Conclusions}

Based on the phenological features of swiddening, the redefined mountainous region or re- 
defined MMSEA, and the multiple thresholds approach of Landsat-derived spectral indices (NDVI, SAVI, NDMI and NBR), the annual extent and area of newly-burned plots (NBP) of swidden agriculture were firstly detected and monitored in the vast mountainous regions of Mainland Southeast Asia (MSEA) during 1988-2016. There was an annual average area of $6.08 \times 10^{4} \mathrm{~km}^{2}$ of newly opened swidden fields, or $3.15 \%$ of the total land area of MSEA in the past nearly three decades. However, the swiddening area opened year by year declined as a whole, especially after 2010 , merely with an average of $5.23 \times 10^{4} \mathrm{~km}^{2}$. This important conclusion comprehensively and robustly validated that the general declining trend of swidden agriculture estimated at local to regional scales in MSEA (Padoch et al., 2007; Schmidt-Vogt et al., 2009; van Vliet et al., 2012). In addition, Myanmar had the largest annual average NBP area of $4.11 \times 10^{4} \mathrm{~km}^{2}$, followed by Thailand with $0.81 \times 10^{4} \mathrm{~km}^{2}$, Vietnam with $0.66 \times 10^{4} \mathrm{~km}^{2}$, Laos with $0.50 \times 10^{4} \mathrm{~km}^{2}$ and Cambodia merely with $42.77 \mathrm{~km}^{2}$, respectively. Finally, the top ten provincial administrative units in Cambodia, Laos, Myanmar, Thailand and Vietnam, which consistently accounted for over $90 \%$ of the area of newly-burned swiddens in each country, showed distinct temporal fluctuations in using slash-and-burn practices in the last nearly three decades. Among them, Mondulkiri (Cambodia), Louang Phrabang (Laos), Shan (Myanmar), Chiang Mai (Thailand) and Son La (Vietnam) were the corresponding provinces with the largest annual average NBP area of swidden agriculture of MSEA countries in an alphabetical order. At the provincial level, there were eight provinces or states with an annual average NBP area larger than $1000 \mathrm{~km}^{2}$, such as Shan State, Chin State, Kayah State, Mandalay from Myanmar, Chiang Mai and Mae Hong Son from Thailand, and Son La and Dien Bien Phu from Vietnam. Among them, Shan State had the largest annual average NBP area of $3.03 \times 10^{4} \mathrm{~km}^{2}$. The resultant 29 Landsat-based 30-m resolution maps of the NBP of swiddening in MSEA comprehensively and timely responded to the first appeal of enhancing swidden agriculture mapping and monitoring with satellite data in two special issues published by the journal of Human Ecology in 2009 (Mertz et al., 2009) and 2013 (van Vliet et al., 2013). We believed that the resultant annual maps of NBP of swidden agriculture lay a solid database for future investigation on local livelihood improvement and environmental effects assessment of this traditional subsistence agriculture in MSEA.

\subsection{Discussion}

Apart from the explicit importance of reconstructing the annual extent and area of $30-\mathrm{m}$ resolution NBP of swidden agriculture, this study might have two critical implications. First, there are two main pathways for monitoring swidden agriculture, which can also be called "Space-Time Conversion" method, namely "Space-for-Time (S-T) substitution" and "Time-for-Space (T-S) substitution", respectively. One is to detect the NBP and swidden fallows at varied stages with single-year remote sensing data. It can be named as the "S-T" substitution as it shows the temporal changes of swidden agriculture through the spatial distribution of varied aged-fallows, from one, five to over 20 years. The swidden fallows at different stages indirectly reflected the temporal development of newly opened swiddens. The other is to detect the NBP of swiddening with inter-annual remotely sensed data. It can be regarded as the "T-S" substitution as it shows the spatial differences of swidden agriculture via the distribution of annual NBP for nearly three decades. The annual extraction of the 
NBP of swidden agriculture also indirectly reflected the general spatial pattern of swidden agriculture.

In our previous study, we placed particular emphasis on developing a simple, effective and feasible algorithm using currently freely available satellite data (e.g. Landsat) at 30-m spatial resolution to detect and map swidden agriculture. However, the fact that the previous study merely utilized single-date multispectral image may limit the capability of the algorithm for fully delineating the actual total distribution of swidden agriculture. The reliability of the results was highly dependent on the selection of Landsat data used in that study. In this updated study, however, all available Landsat TM, ETM+ and OLI scenes acquired between March and May, or in the periods of pre- and post-peak hot-dry season, without considering the level of cloud coverage, in the last nearly three decades were fully utilized to extract the annual actual burned pixels of slash-and-burn to a maximum extent and treated as a comprehensive distribution of swidden agriculture over the mountainous regions of MSEA. The reliable Landsat high-level products data source could ensure the credibility and accuracy of the results, although the combination of the topographical mask with an elevation over $600 \mathrm{~m}$ may omit a small proportion of NBP of swidden agriculture as we noticed in the field work.

Second, Landsat historical archive data especially acquired during the dry season hold great potential in detecting and monitoring the traditional swidden agriculture, also a prevailing, dynamic and complex land use category in the tropics. What makes this study possible is that swidden agriculture has unique phenological features during the dry season. Remotely-sensed data of optical satellites such as Landsat are always questioned and challenged about their applicability in the tropical region due to cloud contamination. This argument is absolutely true in the rainy season ( $\mathrm{Li}$ et al., 2018). However, the half-year dry spells in MSEA greatly facilitate satellites to acquiring less cloud cover observations, especially with the cloud coverage less than or equal to $30 \%$ (Li et al., 2018). Recently, we have analyzed monthly average of cloud cover (less than or equal to 30\%) for Landsat data, including TM, ETM+ and OLI images over MSEA and Yunnan Province in the last three decades. It shows that Landsat has higher probabilities of acquiring high-quality images during the dry season, at a seasonal average of $62 \%$ versus merely $22 \%$ within the rainy season. Monthly averages of $30 \%$ or less than cloud cover were $67 \%$ for January and February, followed by $62 \%$ for March, 56\% for April and November, and 61\% for December. Therefore, we believed that the Landsat historical archive data can be viewed as a robust data source for mapping swidden agriculture, or shifting cultivation, or slash-and-burn farming in the tropics. However, finer spatial resolution data such as Sentinel-2 will greatly improve our understanding of the changes of swidden agriculture in the near future.

With the resultant inter-annual maps of the NBP of swiddening, the changes of spatial patterns over the past 29 years were clearly investigated in this study. Annual area fluctuations in the NBP at the provincial to national level validated the dynamic nature of swidden agriculture. The annual dynamics were closely related to the land use intensity or fallow length of the traditional farming. However, changes in fallow cycle of swidden agriculture and swiddening intensity are typically analyzed at local scale globally. The investigation of fallow period variation contributes to fully understanding the intensity of swidden farming as well as its socio-economic and biophysical effects. Next, we plan to reveal the dynamic changes of fallow length and land use intensity of swidden agriculture in MSEA through the 
probability comparative analysis of the NBP pixels detected each year during 1988-2016.

\section{Acknowledgements}

Landsat data products are freely available from the US Geological Survey (USGS) EROS Data Center. The authors extend their thanks to the anonymous reviewers and editors for their comments that helped to improve this manuscript.

\section{References}

Achard F, Beuchle R, Mayaux P et al., 2014. Determination of tropical deforestation rates and related carbon losses from 1990 to 2010. Global Change Biology, 20(8): 2540-2554.

Achard F, Eva H D, Stibig H J et al., 2002. Determination of deforestation rates of the world's humid tropical forests. Science, 297(5583): 999-1002.

Brady N C, 1996. Alternatives to slash-and-burn: A global imperative. Agriculture, Ecosystems \& Environment, 58(1): 3-11.

Bruun T B, de Neergaard A, Lawrence D et al., 2009. Environmental consequences of the demise in swidden cultivation in Southeast Asia: Carbon storage and soil quality. Human Ecology, 37(3): 375-388.

Cairns M F, 2015. Shifting Cultivation and Environmental Change: Indigenous People, Agriculture and Forest Conservation. New York: Routledge, 1057.

Chuan G K, 2005. The climate of Southeast Asia. In: Gupta A (ed.). The Physical Geography of Southeast Asia. Oxford, UK: Oxford University Press, 80-93.

Cohen P T, 2009. The post-opium scenario and rubber in northern Laos: Alternative Western and Chinese models of development. International Journal of Drug Policy, 20(5): 424-430.

Corlett R T, 2005. Vegetation. In: Gupta A (ed.). The Physical Geography of Southeast Asia. Oxford, UK: Oxford University Press, 105-119.

Cummings A R, Karale Y, Cummings G R et al., 2017. UAV-derived data for mapping change on a swidden agriculture plot: Preliminary results from a pilot study. International Journal of Remote Sensing, 38(8-10): 2066-2082.

Dong J, Xiao X, Menarguez M A et al., 2016. Mapping paddy rice planting area in northeastern Asia with Landsat 8 images, phenology-based algorithm and Google Earth Engine. Remote Sensing of Environment, 185: $142-154$.

Dressler W H, Wilson D, Clendenning J et al., 2016. The impact of swidden decline on livelihoods and ecosystem services in Southeast Asia: A review of the evidence from 1990 to 2015. Ambio, 46(3): 291-310.

Dressler W, Wilson D, Clendenning J et al., 2015. Examining how long fallow swidden systems impact upon livelihood and ecosystem services outcomes compared with alternative land-uses in the uplands of Southeast Asia. Journal of Development Effectiveness, 7(2): 210-229.

Dudal R, 2005. Soil of Southeast Asia. Gupta A (ed.). The Physical Geography of Southeast Asia. Oxford, UK: Oxford University Press, 94-104.

Dutrieux L P, Jakovac C C, Latifah S H et al., 2016. Reconstructing land use history from Landsat time-series: Case study of a swidden agriculture system in Brazil. International Journal of Applied Earth Observation and Geoinformation, 47: 112-124.

Fernández-Manso A, Fernández-Manso O, Quintano C, 2016. SENTINEL-2A red-edge spectral indices suitability for discriminating burn severity. International Journal of Applied Earth Observation and Geoinformation, 50: $170-175$.

Fox J, Castella J, Ziegler A D, 2014. Swidden, rubber and carbon: Can REDD+ work for people and the environment in Montane Mainland Southeast Asia? Global Environmental Change, 29: 318-326.

Fox J, Vogler J B, 2005. Land-use and land-cover change in Montane Mainland Southeast Asia. Environmental Management, 36(3): 394-403. 
Gamon J A, Field C B, Goulden M L et al., 1995. Relationships between NDVI, canopy structure, and photosynthesis in three Californian vegetation types. Ecological Applications, 5(1): 28-41.

García M L, Caselles V, 1991. Mapping burns and natural reforestation using Thematic Mapper data. Geocarto International, 6(1): 31-37.

Goldammer J G, 1988. Rural land-use and wildland fires in the tropics. Agroforestry Systems, 6(3): 235-252.

Gupta A, 2005. Accelerated erosion and sedimentation in Southeast Asia. In: Gupta A (ed.), The Physical Geography of Southeast Asia. Oxford, UK: Oxford University Press, 239-249.

Gupta A, 2005. Landforms of Southeast Asia. In: Gupta A (ed.). The Physical Geography of Southeast Asia. Oxford, UK: Oxford University Press, 38-64.

Hansen P K, 1998. Shifting cultivation development in northern Laos. In: Chapman E C, Bouaham B, Hansen P K. Upland Farming System in the Laos PDR: Problems and Opportunities for Livestock. Vientiane, Laos, Australian Centre for International Agricultural Research (ACIAR): 34-42.

Hett C, Castella J C, Heinimann A et al., 2012. A landscape mosaics approach for characterizing swidden systems from a REDD plus perspective. Applied Geography, 32(2): 608-618.

Huang H, Chen Y, Clinton N et al., 2017. Mapping major land cover dynamics in Beijing using all Landsat images in Google Earth Engine. Remote Sensing of Environment, 202: 166-176.

Huete A R, 1988. A soil-adjusted vegetation index (SAVI). Remote Sensing of Environment, 25(3): 295-309.

Huete A R, Liu H, Van Leeuwen W J, 1997. The use of vegetation indices in forested regions: Issues of linearity and saturation. In: IGARSS. Remote Sensing: A Scientific Vision for Sustainable Development. Singapore, IEEE: 1966-1968.

Hurni K, Hett C, Epprecht M et al., 2013. A texture-based land cover classification for the delineation of a shifting cultivation landscape in the Lao PDR using landscape metrics. Remote Sensing, 5(7): 3377-3396.

Hurni K, Hett C, Heinimann A et al., 2013. Dynamics of shifting cultivation landscapes in Northern Lao PDR between 2000 and 2009 based on an analysis of MODIS time series and Landsat images. Human Ecology, 41(1): 21-36.

Jackson T J, Chen D, Cosh M et al., 2004. Vegetation water content mapping using Landsat data derived normalized difference water index for corn and soybeans. Remote Sensing of Environment, 92(4): 475-482.

Kapos V, Rhind J, Edwards M et al., 2000. Developing a map of the world's mountain forests. In: Price M F, Butt N (ed.). Forests in Sustainable Mountain Development: A State of Knowledge Report for 2000. Task Force on Forests in Sustainable Mountain Development. Oxford: UK, 4-19.

Laurance W F, Sayer J, Cassman K G, 2014. Agricultural expansion and its impacts on tropical nature. Trends in Ecology \& Evolution, 29(2): 107-116.

Li P, Feng Z, 2014. Monitoring phenological stages of swiddening in northern Laos during the dry season. Proc. SPIE 9260, Land Surface Remote Sensing II. Beijing, International Society for Optics and Photonics: 13.

Li P, Feng Z, 2016. Extent and area of swidden in Montane Mainland Southeast Asia: Estimation by multi-step thresholds with Landsat-8 OLI data. Remote Sensing, 8(1): 44.

Li P, Feng Z, Jiang L et al., 2014. A review of swidden agriculture in Southeast Asia. Remote Sensing, 6(2): $1654-1683$.

Li P, Feng Z, Xiao C, 2018. Acquisition probability differences in cloud coverage of the available Landsat observations over mainland Southeast Asia from 1986 to 2015. International Journal of Digital Earth, 11(5): 437-450.

Liao C, Feng Z, Li P et al., 2015. Monitoring the spatio-temporal dynamics of swidden agriculture and fallow vegetation recovery using Landsat imagery in northern Laos. Journal of Geographical Sciences, 25(10): $1218-1234$.

Manivong V, Cramb R A, 2008. Economics of smallholder rubber expansion in Northern Laos. Agroforestry Systems, 74(2): 113-125.

Masek J G, Vermote E F, Saleous N E et al., 2006. A Landsat surface reflectance dataset for North America, 1990-2000. IEEE Geoscience and Remote Sensing Letters, 3(1): 68-72.

Mertz O, Leisz S, Heinimann A et al., 2009. Who counts? Demography of swidden cultivators in Southeast Asia. 
Human Ecology, 37(3): 281-289.

Mertz O, Padoch C, Fox J et al., 2009. Swidden change in Southeast Asia: Understanding causes and consequences. Human Ecology, 37(3): 259-264.

Messerli P, Heinimann A, Epprecht M, 2009. Finding homogeneity in heterogeneity: A new approach to quantifying landscape mosaics developed for the Lao PDR. Human Ecology, 37(3): 291-304.

Michaud J, 2010. Editorial-Zomia and beyond. Journal of Global History, 5(2): 187-214.

Padoch C, Coffey K, Mertz O et al., 2007. The demise of swidden in Southeast Asia? Local realities and regional ambiguities. Geografisk Tidsskrift-Danish Journal of Geography, 107(1): 29-41.

Rerkasem K, Lawrence D, Padoch C et al., 2009. Consequences of swidden transitions for crop and fallow biodiversity in Southeast Asia. Human Ecology, 37(3): 347-360.

Rerkasem K, Yimyam N, Rerkasem B, 2009. Land use transformation in the mountainous mainland Southeast Asia region and the role of indigenous knowledge and skills in forest management. Forest Ecology and Management, 257(10): 2035-2043.

Schmidt-Vogt D, Leisz S J, Mertz O et al., 2009. An assessment of trends in the extent of swidden in Southeast Asia. Human Ecology, 37(3): 269-280.

Stibig H, Achard F, Carboni S et al., 2014. Change in tropical forest cover of Southeast Asia from 1990 to 2010. Biogeosciences, 11(2): 247.

Stibig H J, Achard F, Fritz S, 2004. A new forest cover map of continental southeast Asia derived from SPOT-VEGETATION satellite imagery. Applied Vegetation Science, 7(2): 153-162.

Stibig H J, Belward A S, Roy P S et al., 2007. A land-cover map for South and Southeast Asia derived from SPOT-VEGETATION data. Journal of Biogeography, 34(4): 625-637.

Tian Y, Wu B, Zhang L et al., 2011. Opium poppy monitoring with remote sensing in North Myanmar. International Journal of Drug Policy, 22(4): 278-284.

Tucker C J, Justice C O, Prince S D, 1986. Monitoring the grasslands of the Sahel 1984-1985. International Journal of Remote Sensing, 7(11): 1571-1581.

U.S. Geological Survey (USGS), 2016. USGS Earth Resources Observation and Science (EROS) Center Science Processing Architecture (ESPA) On Demand Interface (Version 3.3).

Van Schendel W, 2002. Geographies of knowing, geographies of ignorance: Jumping scale in Southeast Asia. Environment and Planning D: Society and Space, 20(6): 647-668.

van Vliet N, Mertz O, Birch-Thomsen T et al., 2013. Is there a continuing rationale for swidden cultivation in the 21st century? Human Ecology, 41(1): 1-5.

van Vliet N, Mertz O, Heinimann A et al., 2012. Trends, drivers and impacts of changes in swidden cultivation in tropical forest-agriculture frontiers: A global assessment. Global Environmental Change, 22(2): 418-429.

Vogelmann J E, Rock B N, 1988. Assessing forest damage in high-elevation coniferous forests in Vermont and New Hampshire using Thematic Mapper data. Remote Sensing of Environment, 24(2): 227-246.

Woodcock C E, Allen R, Anderson M et al., 2008. Free access to Landsat imagery. Science, 320(5879): 1011-1012.

Xiao C W, Li P, Feng Z M et al., 2018. Spatio-temporal differences in cloud cover of Landsat-8 OLI observations across China during 2013-2016. Journal of Geographical Sciences, 28(4): 429-444.

Zhu Z, Woodcock C E, 2012. Object-based cloud and cloud shadow detection in Landsat imagery. Remote Sensing of Environment, 118: 83-94.

Ziegler A D, Bruun T B, Guardiola-Claramonte M et al., 2009. Environmental consequences of the demise in swidden cultivation in Montane Mainland Southeast Asia: Hydrology and deomorphology. Human Ecology, 37(3): 361-373.

Ziegler A D, Fox J M, Webb E L et al., 2011. Recognizing contemporary roles of swidden agriculture in transforming landscapes of Southeast Asia. Conservation Biology, 25(4): 846-848.

Zwartendijk B W, van Meerveld H J, Ghimire C P et al., 2017. Rebuilding soil hydrological functioning after swidden agriculture in eastern Madagascar. Agriculture, Ecosystems \& Environment, 239: 101-111. 